\title{
Phytoaccumulation of Arsenic, Cadmium and Lead by Brassica juncea Parents and Their F1 Hybrids
}

\author{
Moupia Rahman*, Nazmul Haq, Ian D. Williams \\ Environment Division, School of Civil Engineering and the Environment, University of Southampton, \\ Southampton, UK \\ Email: "moupia2004@yahoo.com
}

Received 28 January 2016; accepted 4 April 2016; published 7 April 2016

Copyright (C) 2016 by authors and Scientific Research Publishing Inc.

This work is licensed under the Creative Commons Attribution International License (CC BY). http://creativecommons.org/licenses/by/4.0/

(c) $\underset{\mathrm{EY}}{\mathbf{E}}$ Open Access

\section{Abstract}

Although Brassica juncea (Indian mustard) is reported to be a good accumulator of metals, little is known of the selected varieties of $B$. juncea (cvs. Rai and BARI-11). This paper investigates the phytoaccumulation of arsenic, cadmium and lead by B. juncea (cvs. Rai and BARI-11) parents and F1 hybrids. The experiment was conducted in the hydroponic media in the greenhouse of University of Southampton under a Randomised Block Design. Sodium arsenite, cadmium sulphate and lead nitrate with $0 \mathrm{ppm}, 0.5 \mathrm{ppm}$ and $1 \mathrm{ppm}$ were used. The cadmium treated plants were analysed by Varian Atomic absorption spectrophotometer-200. The samples of arsenic and lead were analysed by Inductively Coupled Plasma Atomic Emission Spectrophotometer. The results suggest that arsenic was detected only in the root systems while cadmium and lead were detected both in the root and shoot systems. Significant differences in the uptake were observed for different concentrations. Accumulation of arsenic was detected only in the root systems of $B$. juncea (cvs. Rai and BARI-11) at lower concentrations. Hence, this can be used as an agriculturally viable and efficient phytoaccumulator in the arsenic affected areas where contamination level is low and the contamination occurs at the rooting level.

\section{Keywords}

Bioremediation, Phytoaccumulation, Heavy Metal, Arsenic, Cadmium, Lead, B. juncea (cvs. Rai and BARI-11)

\footnotetext{
${ }^{*}$ Corresponding author.
}

How to cite this paper: Rahman, M., Haq, N. and Williams, I.D. (2016) Phytoaccumulation of Arsenic, Cadmium and Lead by Brassica juncea Parents and Their F1 Hybrids. Journal of Environmental Protection, 7, 613-622. 


\section{Introduction}

The presence of Heavy metals in the environment is a natural phenomenon, although anthropogenic activities also add Heavy metals to the environment. Heavy metals as contaminants to the environment are causes of concern in many parts of the world. Among the potentially toxic metals, arsenic (As), cadmium (Cd) and lead (Pb) in particular, can cause adverse effects on agriculture [1]-[12]. The presence of high concentrations of metals in soil may pose a significant threat to agriculture, through bioaccumulation and consequently may affect the public health by contaminating the food chain [7] [11] [13]-[17].

Scientists have discovered physical and chemical remediation technologies to clean up contaminated sites [18]-[20] involving excavation, burial, ex-situ treatment, in-situ (chemistry-bioremediation), encapsulation, ion exchange reverse osmosis [18] and natural attenuation [21] [22]. These technologies can be expensive and impractical considering the notable area contaminated by metals around the world [15] [20] [23] [24].

Plants play a significant role in maintaining the environment, particularly through the management of soil. They have the ability to remediate contaminated land by uptaking metals from soil and can reduce the adverse impacts of anthropogenic air pollution by absorbing $\mathrm{CO}_{2}$ emitted by combustion processes via photosynthesis [20] [25]. A plant-based technology ("phytoaccumulation") has been used to remediate metals from contaminated areas, and found to be cost effective and eco-friendly [12] [24] [26]-[28]. After plant uptake heavy metals the harvested plant parts can be classified as a hazardous waste and should be disposed of in such a way that the pollutants do not re-enter in to the environment. One way of doing this is to separate the heavy metal through precipitation and solidification for future industrial use. Macnair [29] provided a list of plant species, which are known to be phytoaccumulators for a range of potentially toxic metals and a number of them belong to the family Brassicaceae.

Several species of B. juncea (Indian mustard) can accumulate heavy metals (cadmium, arsenic and lead) from soil and aqueous solution through their root system and then can transport it to different parts of shoots [30]. However, the uptake behaviour of different varieties of B. juncea has been found to vary [31]. Although $B$. juncea is reported to be a good accumulator of metals [32], little is known of the selected varieties of $B$. juncea cv. Rai and B. juncea cv. BARI-11 and their ability to uptake metals. In addition, the effect of different concentrations of metals, such as arsenic, cadmium and lead on these two varieties has not been determined, although these are grown in most areas affected by these metals [32]. This paper investigates the phytoaccumulation of arsenic, cadmium and lead by B. juncea (cv. Rai and BARI-11) parents and F1 hybrids. The reason for considering F1 hybrids is that these are intermediate generation with unstable genetic characteristics, hence may show different result than the parents. Also in Bangladeshi context when farmer use their own seed stock these are likely to be the F1 hybrids of the two parents as the parents are cultivated in the adjacent fields.

\section{Methodology}

The experiment was conducted in the hydroponic media in the greenhouse of University of Southampton under a Randomised Block Design (RBD) [33] involving B. juncea parents and their F1 hybrids. A hydroponic system is the cultivation of plants without (or minimal) soil to support the root system. In comparison to a conventional method, a hydroponic system permits better characterisation of pollutant uptake because of potential interaction between the soil matrix and the elements of interest are minimized [34] [35]. The hydroponic growing media allows adequate root distribution of plants and maintains homogeneous conditions of growing media, which is restricted in pot plant experiments [27] [36]-[38]. Furthermore, plants can uptake and translocate the soluble forms of metals easily in the hydroponic systems. It should be noted that a modified hydroponic system was used in this study where individual plastic containers were used to grow plants and nutrient solutions and metal concentrations were maintained manually.

The chemical forms of metals used in this experiment were arsenic as sodium arsenite, cadmium as cadmium sulphate and lead as lead nitrate. All of these chemical forms are soluble and were used in other studies conducted by Hossain [6], Kumar et al. [39] and Cox et al. [40].

The literature suggests that most of the studies involving Brassica species were conducted in the hydroponic conditions with concentrations of arsenic, cadmium and lead ranging from 0 - 1 ppm [6] [39] [40]. In the current study, 0.5 ppm and 1 ppm of arsenic, cadmium and lead were used.

\subsection{Design of Experiment}

Randomized Block Design (RBD) [33] was used with the aim of studying the variation in selected morphologi- 
cal characteristics of two varieties, cv. Rai (P1) and cv. BARI-11 (P2) of B. juncea, and their reciprocal F1hybrids in accumulating arsenic, cadmium and lead. Parents and hybrids were considered as blocks and different concentrations of metals were considered as treatments.

Three treatments of the experiment were $\mathrm{R}_{1}=0.0 \mathrm{ppm}$ (control treatment), $\mathrm{R}_{2}=0.5 \mathrm{ppm}$ and $\mathrm{R}_{3}=1.0 \mathrm{ppm}$. Treatments were allocated randomly in each block. The RBD in this experiment consisted of multiple observations (r) per cell, where the number was 4 per cell. As the RBD conducted in this experiment had multiple observations per cell the analyses allowed an investigation of the combined effect, namely the interaction effects of concentrations of metals and parents and hybrids [41].

\subsection{Growing Plants for Experiment}

The experiment was carried out in a greenhouse at the University of Southampton, UK, during April-June 2006. The recorded temperature ranged between $14^{\circ} \mathrm{C}-35^{\circ} \mathrm{C}\left(\mathrm{SD}= \pm 5^{\circ} \mathrm{C}\right)$, light intensity was $750-1980$ lux and day length was 13 - 16 hours per day. Transparent plastic containers (1.5 feet $\times 1$ feet $\times 1$ feet $)$ were used to grow plants and these enabled the maintenance of nutrient levels and the observation of plant root systems.

Each container was filled with twenty litres of full strength Hoagland solution, which were prepared following [34]. Iron was avoided in preparing the Hoagland solution as it has been reported to interfere with uptake of metals [42]. For example, Brown [43], Cohen et al. [42] and, Bao and Sun [44] used Hoagland solution in their experiments without iron to avoid its influence on uptake of metals. Twenty litres of nutrient solutions were made using stock solutions of $20 \mathrm{ml}$ of ammonium di-hydrogen phosphate, $120 \mathrm{ml}$ potassium nitrate, $80 \mathrm{ml}$ calcium nitrate, $40 \mathrm{ml}$ magnesium sulphate and $20 \mathrm{ml}$ micronutrient solution and were added into $1720 \mathrm{ml}$ of water.

Seeds of B. juncea cv. Rai (P1), B. juncea cv. BARI-11 (P2) and their F1 hybrids were germinated in the mixture of perlite and soil (3:1volume) in the greenhouse. Plants were allowed to grow for two weeks so that they achieved sufficient growth to be suitable for transplantation. Two week old seedlings were transferred to the experimental containers. Metals were added to the growing media after one week of transplantation of the seedlings. All containers were covered with black polythene sheets to avoid possible growth of algae due to exposure to sunlight. Each container was marked at twenty litres and this level was maintained daily by topping up with the same concentration of plant nutrients and metals as originally used [40]. The $\mathrm{pH}$ level of growing media was estimated using "pHtesting colour strip" (pH-Fix 0-14, Fisherbrand; EU code: FB33003). Aeration was maintained by continuous air bubbling $(210 \mathrm{~L} / \mathrm{hr}$ air flow and $0.17 \mathrm{mbar}$ pressure) in the growing media by air pumps.

\subsection{Determination of Metals}

Plants treated with arsenic, cadmium and lead were harvested and rinsed with deionised water to remove any nutrient solution and dried for 24 hours at $65^{\circ} \mathrm{C}$ [40]. Dried samples were homogenised using a Cyclotech Mill and stored in small plastic containers. A microwave digestion [45] procedure was followed to digest the plant material. The cadmium treated plants were analysed by Varian Atomic absorption spectrophotometer-200. The samples of arsenic and lead were analysed by Inductively Coupled Plasma Atomic Emission Spectrophotometer (ICP-AES).

\subsection{Statistical Analysis}

The experimental data were analysed using two-way analysis of variance (ANOVA). It should be noted that every characteristic under study was subject to testing of the same set of hypotheses (null and alternative). Hence, a separate ANOVA table for each characteristic was produced. The normality of the data was tested using the Kolmogorov-Smirnov test. The analysis of variance and the Post hoc tests were conducted using MINITAB 15 software.

\section{Results}

\subsection{Effect of Arsenic Concentrations}

The result suggests that arsenic was detected only in the root systems of $B$. juncea parents and their hybrids. Table 1 shows the mean and standard error of root uptake of P1 (B. juncea cv. Rai) and P2 (B. juncea cv. BARI-11) 
Table 1. Mean (standard error) of root uptake and shoot uptake of parents B. juncea cv. Rai (P1), B. juncea cv. BARI-11

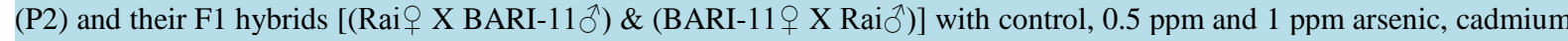
and lead treatments $(n=4)$.

\begin{tabular}{|c|c|c|c|c|c|c|}
\hline \multirow{2}{*}{$\begin{array}{l}\text { Parents and F1 } \\
\text { hybrids }\end{array}$} & \multirow[b]{2}{*}{ Concentrations } & \multirow{2}{*}{$\begin{array}{c}\text { Arsenic } \\
\begin{array}{c}\text { Root uptake } \\
\text { (mg/g) }\end{array}\end{array}$} & \multicolumn{2}{|c|}{ Cadmium } & \multicolumn{2}{|c|}{ Lead } \\
\hline & & & $\begin{array}{l}\text { Root uptake } \\
\text { (mg/g) }\end{array}$ & $\begin{array}{l}\text { Shoot uptake } \\
\text { (mg/g) }\end{array}$ & $\begin{array}{l}\text { Root uptake } \\
\text { (mg/g) }\end{array}$ & $\begin{array}{l}\text { Shoot uptake } \\
\text { (mg/g) }\end{array}$ \\
\hline \multirow[t]{3}{*}{ P1 } & Control & $0.0(0.0)$ & $0.0(0.0)$ & $0.0(0.0)$ & $0.0(0.0)$ & $0.0(0.0)$ \\
\hline & $0.5 \mathrm{ppm}$ & $0.6(0.0)$ & $1.9(0.1)$ & $0.3(0.0)$ & $2.2(0.6)$ & $0.05(0.0)$ \\
\hline & $1.0 \mathrm{ppm}$ & $0.7(0.1)$ & $2.3(0.2)$ & $0.4(0.1)$ & $2.4(0.3)$ & $0.07(0.0)$ \\
\hline \multirow[t]{3}{*}{ P2 } & Control & $0.0(0.0)$ & $0.0(0.0)$ & $0.0(0.0)$ & $0.0(0.0)$ & $0.0(0.0)$ \\
\hline & $0.5 \mathrm{ppm}$ & $0.4(0.1)$ & $1.4(0.2)$ & $0.3(0.0)$ & $1.7(0.3)$ & $0.03(0.0)$ \\
\hline & $1.0 \mathrm{ppm}$ & $0.7(0.1)$ & $2.2(0.3)$ & $0.5(0.0)$ & $2.5(0.1)$ & $0.08(0.0)$ \\
\hline \multirow[t]{3}{*}{ F1 } & Control & $0.0(0.0)$ & $0.0(0.0)$ & $0.0(0.0)$ & $0.0(0.0)$ & $0.0(0.0)$ \\
\hline & $0.5 \mathrm{ppm}$ & $0.3(0.6)$ & $0.7(0.5)$ & $0.3(0.0)$ & $1.1(1.0)$ & $0.07(0.0)$ \\
\hline & $1.0 \mathrm{ppm}$ & $1.0(0.1)$ & $1.9(0.5)$ & $0.6(0.0)$ & $1.1(0.3)$ & $0.06(0.0)$ \\
\hline \multirow[t]{3}{*}{$\mathrm{RF} 1$} & Control & $0.0(0.0)$ & $0.0(0.0)$ & $0.0(0.0)$ & $0.0(0.0)$ & $0.0(0.0)$ \\
\hline & $0.5 \mathrm{ppm}$ & $0.4(0.1)$ & $0.8(0.5)$ & $0.5(0.0)$ & $0.1(0.0)$ & $0.06(0.0)$ \\
\hline & $1.0 \mathrm{ppm}$ & $1.0(0.2)$ & $3.1(0.2)$ & $0.7(0.1)$ & $1.9(1.0)$ & $0.05(0.0)$ \\
\hline
\end{tabular}

parents and F1 (Rai + X BARI-11ठ) and RF1 (BARI-11우 X Rai $\delta^{\Uparrow}$ ) hybrids. The mean root uptake of P1 was higher than that of P2 $(0.4 \mathrm{mg} / \mathrm{g})$ at $0.5 \mathrm{ppm}$ concentration of arsenic but the differences were not statistically significant (Table 1). With the increase of the arsenic concentration to $1 \mathrm{ppm}$ all parents and hybrids showed significant increase in root uptake compared to $0.5 \mathrm{ppm}$. The increase in mean root uptake of F1 and RF1 was significantly higher compared to that of P1 and P2. The analysis suggested that root uptake differed significantly $(p<0.01)$ between different concentrations of arsenic (Table 2). The interaction effect (combined effect of parent and hybrids and concentration) was significant for root uptake $(p<0.01)$.

\subsection{Effect of Cadmium Concentrations}

The results suggested that cadmium was detected both in the root and shoot systems of two B. juncea parents and their hybrids. The mean and standard error of root uptake and shoot uptake of parents B. juncea cv. Rai (P1), B. juncea cv. BARI-11 (P2) and their F1 (Rai 9 X BARI-11 $\bigcirc^{\lambda}$ ) and RF1 (BARI-11ㅇ X Rai $\overbrace{}^{\lambda}$ ) hybrids are presented in Table 1.

Root uptake of P1 was significantly higher than that of P2 at 0.5 ppm concentration of cadmium (Table 1). At $0.5 \mathrm{ppm}$, both the F1 and RF1 had significantly less root uptake than their parents. At $1 \mathrm{ppm}$, all the parents and hybrids had significantly increased root uptake compared to $0.5 \mathrm{ppm}$. Root uptake was significantly $(p<0.05)$ different between cadmium concentrations (Table 2). At $1 \mathrm{ppm}$ concentration of cadmium root uptake of parents and hybrids was higher compared to that at $0.5 \mathrm{ppm}$, though the differences were not statistically significant.

At $0.5 \mathrm{ppm}$ concentration of cadmium P1, P2 and F1 had more or less similar shoot uptake $(0.3 \mathrm{mg} / \mathrm{g})$, which was almost twice for RF1 (0.5 mg/g) (Table 1). At1 ppm, all the parents and hybrids had significantly increased shoot uptake compared to $0.5 \mathrm{ppm}$. In general, shoot uptake was much less than the root uptake for both the cadmium concentrations. Shoot uptake was significantly $(p<0.01)$ different between cadmium concentrations. Furthermore, shoot uptake was significantly $(p<0.01)$ different between parents and their F1 hybrids (Table 2). Significant interaction effect (between concentrations and parents and hybrids) was found for shoot uptake ( $p<$ $0.01)$. 
Table 2. Two-way ANOVA for root and shoot uptake of parents B. juncea cv. Rai (P1), B. juncea cv. BARI-11 (P2) and

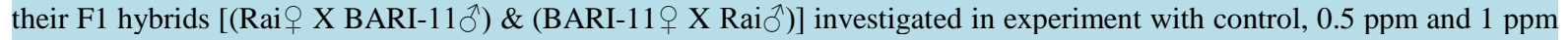
arsenic, cadmium and lead concentrations.

\begin{tabular}{cccccc}
\hline \multirow{2}{*}{ Sources of variation } & Arsenic & \multicolumn{2}{c}{ Cadmium } & \multicolumn{2}{c}{ Lead } \\
\cline { 2 - 6 } & Root uptake & Root uptake & Shoot uptake & Root uptake & Shoot uptake \\
Concentrations & $103.3^{* * *}$ & $55.5^{* * *}$ & $273.5^{* * *}$ & $16.9^{* * *}$ & $127.1^{* * *}$ \\
Parents and hybrids & 0.6 & 1.5 & $14.6^{* * *}$ & 2.4 & 0.5 \\
Concentrations X Parents and hybrids & $3.3^{* * *}$ & 2.0 & $5.1^{* * *}$ & 1.3 & $5.9^{* * *}$ \\
\hline
\end{tabular}

Note: ${ }^{* * *} p<0.01,{ }^{* *} p<0.05$; Values represent F-values from ANOVA. Degrees of freedom for treatment, parents and hybrids, interaction and error were 2, 3, 6 and 36 respectively.

\subsection{Effect of Lead Concentrations}

Results revealed that lead was detected in both the root and shoot systems of parents and F1 hybrids. Table 1 shows the mean and standard error of root uptake and shoot uptake of parents B. Juncea cv. Rai (P1), B. Juncea cv. BARI-11 (P2) and their F1 (Rai 9 X BARI-11 ${ }^{1}$ ) and RF1 (BARI-11 $q$ X Rai ${ }^{\wedge}$ ) hybrids.

P1 had higher (insignificant) mean root uptake than P2 at $0.5 \mathrm{ppm}$ concentrations of lead (Table 1). Both the F1 and RF1 had significantly lower root uptake compared to their parents at $0.5 \mathrm{ppm}$. At $1 \mathrm{ppm}$, all parents and hybrids had increased root uptake compared to $0.5 \mathrm{ppm}$. The increase was significant in P2.Root uptake was significantly ( $p<0.01$ ) different between concentrations of lead (Table 2). Even though, root uptake of lead showed notable difference between parents and hybrids these were not statistically significant.

Shoot uptake of all parents and hybrids were negligible at both the concentrations $(0.5 \mathrm{ppm}$ and $1 \mathrm{ppm})$ of lead (Table 1). At $0.5 \mathrm{ppm}$ concentrations of lead P1 and P2 had shoot uptake as $0.05 \mathrm{mg} / \mathrm{g}$ and $0.03 \mathrm{mg} / \mathrm{g}$ respectively, which were $0.07 \mathrm{mg} / \mathrm{g}$ and $0.06 \mathrm{mg} / \mathrm{g}$ for F1 and RF1 respectively. At $1 \mathrm{ppm}, \mathrm{P} 1$ and P2 had increase while F1 and RF1 had little decrease in shoot uptake compared to $0.5 \mathrm{ppm}$. Generally, shoot uptake for lead concentrations ( $0.5 \mathrm{ppm}$ and $1 \mathrm{ppm})$ was much less than the root uptake for all parents and hybrids. Shoot uptake was significantly different $(p<0.01)$ between concentrations of lead (Table 2). Significant interaction effect (between concentrations and parents and hybrids) was found for shoot uptake $(p<0.01)$.

\section{Discussion}

\subsection{Arsenic Concentrations}

In this experiment, an inorganic form of arsenic (sodium arsenite) was used. As an inorganic substance exists as ions, it is generally taken up via the membrane transporter proteins [24]. When inorganic pollutants are accumulated in tissues they often cause toxicity by inducing oxygen free radicals, which is called the oxidative stress [46] [47]. The oxidative stress is harmful to tissues causing damage to cell structure [24]. Moreover, it was reported that plants can generate a mechanism, known as detoxification, by producing phytochelatin that detoxifies arsenic after certain periods of oxidative stress [47]-[49]. All of these three mechanisms, e.g., transporting of arsenic, toxification and detoxification of arsenic may have different impacts on morphological characteristics expressing different association with uptake behaviour. Furthermore, the same mechanism may act differently between root and shoot systems due to the difference between cell structures of root and shoot. It should be noted that as F1 hybrids are expected to have different genetic combinations from parents, they may show different responses to the above mechanisms. The mechanisms mentioned above are likely to be present for other metals, e.g., cadmium and lead, as inorganic forms of the metals were used in this experiment, which are discussed in appropriate sections. As the current study was not intended to investigate the existing mechanisms reported in different literature, any specific interpretations of the results may not be possible. However, attempts are made to relate the findings that are observed elsewhere.

It is apparent from the results that arsenic was detected in the root systems of $B$. juncea parents and their hybrids but not in the shoot systems. A study by Pickering et al. [50] on B. juncea var. 426,308 with $250 \mu \mathrm{M}$ of arsenic (arsenate V) reported that arsenic uptake was concentrated mostly in the root system with a small fraction exported into the shoot system. The reason for no arsenic accumulation in the shoot system may be that arsenite 
[As (III)] form of arsenic was used in the present study. Generally, arsenite is more toxic than arsenate for plants because it reacts with sulfyhydryl groups (-SH) in enzymes and tissue proteins of the root [51]. Consequently, it leads to inhibition of cellular function and death [52], resulting in failure of transportation of arsenic into the shoot [31].

The mean root uptake of P1 was slightly higher than that of P2, while root uptake of hybrids was less than their parents at $0.5 \mathrm{ppm}$ concentration of arsenic. At $1 \mathrm{ppm}$ concentration of arsenic all parents and hybrids showed increase in root uptake; the increase was much higher in hybrids than the parents. Generally, with increase in concentrations of arsenic the uptake seemed to increase in B. juncea L. [31] [50] until certain level of toxicity [3]. Hybrids are made up with combination of characteristics from both parents and can sometimes behave extremely differently [53]. More precisely, F1 hybrids are intermediate generation and may possess some genetic advantage leading to higher uptake of arsenic than their parents.

The analysis further suggested that root uptake differed significantly $(p<0.01)$ between different concentrations of arsenic. This may suggest that plants respond to different concentrations (toxicity) differently which finally results in different level of uptake. A significant interaction effect (combined effect of parent and hybrids and concentration) was also found for root uptake. This means that the action of the same concentration may impact differently for parents and their hybrids. Genotypic differences between parents and hybrids and their response to concentrations may be one of the reasons behind such phenomenon. However, this requires further investigation.

\subsection{Cadmium Concentrations}

For cadmium concentrations both root and shoot uptake were detected in the experiment. Similar was reported by Salt et al. [54], Fujimura et al. [55] in B. juncea var. 426308 and by Vatehova et al. [56] in Brassica juncea (L.) Czern. cv. Vitasso and B. napus L. cv. Atlantic, and Wue et al. [57] in H. vulgare. Both F1 and RF1 had less root uptake compared to parents though, P1 had slightly higher root uptake than that of P2 at 0.5 ppm concentration of cadmium. When concentration of cadmium was increased to $1 \mathrm{ppm}$ all the parents and hybrids had much higher amount of root uptake compared to that achieved at $0.5 \mathrm{ppm}$. Root uptake was significantly different between cadmium concentrations.

At 0.5 ppm concentration of cadmium both the parents and F1had almost similar shoot uptake. Shoot uptake of RF1 was almost twice compared to parents. At $1 \mathrm{ppm}$, all the parents and hybrids experienced increase in shoot uptake. In general, shoot uptake was much less than the root uptake for both the cadmium concentrations. Significant difference was observed for shoot uptake between cadmium concentrations and between parents and their F1 hybrids. Also a significant interaction effect (between concentrations and parents and hybrids) was found.

In general, uptake of cadmium by root system was found higher than that by shoot system in this study. Fujimura et al. [55] reported similar findings that cadmium concentration was always higher in roots than shoots for Brassicas. This finding also corroborates with the results of number of other investigations conducted by Salt $e t$ al. [54] in B. juncea var. 426308 and Wue et al. [57] in $H$. vulgare. This may be due to the barrier caused by endodermis that restricts the movement of cadmium into shoot system from root system. Such a mechanism has been reported for other metals, such as, lead in O. sativa [58]. At 1ppm, root uptake and shoot uptake were found to be increased compared to $0.5 \mathrm{ppm}$. Several other studies also reported that cadmium accumulation in roots and shoots increased with the increase in concentrations [8] [27] [57].

\subsection{Lead Concentrations}

Accumulation of lead was detected both in root and shoot systems in the experiment with different lead concentrations. Similar results were reported by others, for example, Liu et al. [59] in B. juncea var. Megarrhiza, Meyers et al. [60] and Kumar et al. [39] in B. juncea, Jones et al. [61] in rye grass and Lane and Martin [62] in R. sativus. Significant difference of root uptake was observed between concentrations of lead which may be due to the differences in responses to toxicity associated with different lead concentrations.

Shoot uptake of all parents and hybrids were very negligible at $0.5 \mathrm{ppm}$ concentration of lead. At $1 \mathrm{ppm}$, shoot uptake was increased in P1 and P2 but it was decreased in F1 and RF1. Shoot uptake was significantly different between concentrations of lead. Again, significant interaction effect (between concentrations and parents and hybrids) was found for shoot uptake. It indicates that various concentrations of lead may interact differently with 
parents and hybrids leading to differences in uptake.

The findings of this experiment with lead concentrations revealed that root uptake was much higher than shoot uptake for all parents and hybrids. Similar observations were made by other studies in B. juncea [39] [62]. Generally, lead moves into the root apoplast and finally across the cortex and accumulates near the endodermis [5] causing barrier for translocation of lead from root system to shoot system [58] [61]. This may lead to reduced accumulation of lead by shoot system than root system. The negligible amount of uptake of lead in shoot system observed in the experiment may be due to such mechanisms, which requires further investigation.

\section{Conclusion}

In this study, accumulation of arsenic was detected only in the root system of B. juncea (cvs. Rai and BARI-11) at lower concentrations. In many of the arsenic affected countries/regions like Bangladesh, West Bengal of India, Nepal, Vietnam, and southern China [14] [15] [63] B. juncea is a much cultivated oil seed crop [64] [65]. Among these arsenic affected areas where contamination level is low and the contamination occurs at the rooting level, B. juncea (cvs. Rai and BARI-11) can be used as an agriculturally viable and efficient phytoaccumulator. In such case only root parts of $B$. juncea will extract the arsenic and shoot system will not be affected, which will encourage the farmers to harvest oil seeds and consequently remediate the soil. However, the disposal of accumulated arsenic in the root system will be an important task for the farmers that should be handled carefully. Furthermore, the accumulated arsenic can be used for industrial purposes after extracting from the root system. If B. juncea (cvs. Rai and BARI-11) shows arsenic accumulation only in root system even at higher concentration, it will widen its potential as a sustainable phytoremediation tool for many arsenic affected areas of the world. For the other two potentially toxic metals (cadmium and lead) B. juncea (cvs. Rai and BARI-11) is found to be good accumulator too. However, as both root and shoot uptake is evident for the two metals (cadmium and lead) these are not agriculturally viable. For all the three metals (arsenic, cadmium and lead) further experiments may be conducted with higher concentrations. Finally, it should be kept in mind that the experiment of the study was performed in aqueous solution, hence the results may not exactly be the same in soil medium or in practical application. Future research should consider the presence and interaction of other soil based chemicals on phytoaccumulation.

\section{References}

[1] Chaney, R.L. and Ryan, J.A. (1994) Risk Based Standards for Arsenic, Lead and Cadmium in Urban Soils. Dechema, Frankfurt.

[2] Erick, M.J., Peak, J.D., Brady, P.V. and Pesek, J.D. (1999) Kinetics of Lead Adsorption and Desorption on Goethite: Residence Time Effect. Soil Science, 164, 28-39. http://dx.doi.org/10.1097/00010694-199901000-00005

[3] Miteva, E. (2002) Accumulation and Effect of Arsenic on Tomatoes. Communications in Soil Science and Plant Analysis, 33, 1917-1926. http://dx.doi.org/10.1081/CSS-120004832

[4] McArthur, J.M., Banjeree, D.M., Hudson-Edwards, K.A., Mishra, R., Purohit, R., Ravenscroft, P., Cronin, A., Howarth, R.J, Chaterjee, A., Talukder, T., et al. (2004) Natural Organic Matter in Sedimentary Basins and Its Relation to Arsenic in Anoxic Ground Water: The Example of West Bengal and Its Worldwide Implications. Applied Geochemistry, 19, 1255-1293. http://dx.doi.org/10.1016/j.apgeochem.2004.02.001

[5] Sharma, P. and Dubey, R.S. (2005) Lead Toxicity in Plants. Brazilian Journal of Plant Physiology, 17, 35-52. http://dx.doi.org/10.1590/S1677-04202005000100004

[6] Hossain, M.F. (2006) Arsenic Contamination of Bangladesh-An Overview. Agriculture Ecosystem and Environment, 113, 1-16. http://dx.doi.org/10.1016/j.agee.2005.08.034

[7] Prasad, M.N.V. (2006) Plants That Accumulate and/or Exclude Toxic Trace Elements Play an Important Role in Phytoremediation. In: Prasad, M.N.V., Ed., Trace Element in the Environment, Taylor and Francis Group LLC, Boca Raton, 524-547.

[8] Dominguez, F.A.S., Chavez, M.C.G., Gonzalez, C.R. and Vazquez, R.R. (2007) Accumulation and Localization of Cadmium in Echinochola polystachya Grown within a Hydroponics System. Journal of Hazardous Materials, 141, 630-636. http://dx.doi.org/10.1016/j.jhazmat.2006.07.014

[9] Murakami, M. and Ishikawa, S. (2007) Phytoextraction of Cadmium by Rice, Soybean and Maize. Environmental Pollution, 145, 96-103. http://dx.doi.org/10.1016/j.envpol.2006.03.038

[10] Simonova, E., Hensilova, M., Masarovicova, E. and Kohanova, J. (2007) Comparison of Tolerance of Brassica juncia and Vigna radiata to Cadmium. Biologia Plantarum, 51, 488-492. http://dx.doi.org/10.1007/s10535-007-0103-z 
[11] Chen, S., Chen, L., Ma, Y. and Huang, Y. (2009) Can Phosphate Compounds Be Used to Reduce the Plant Uptake of Lead and Resists the Lead Stress in Lead-Contaminated Soils? Journal of Environmental Science, 21, 360-365. http://dx.doi.org/10.1016/S1001-0742(08)62277-9

[12] Tangahu, B.V., Abdullah, S.R.S., Basri, H., Idris, M., Anuar, N. and Mukhlisin, M. (2011) A Review on Heavy Metals (As, $\mathrm{Pb}$, and $\mathrm{Hg}$ ) Uptake by Plants through Phytoremediation. International Journal of Chemical Engineering, 2011, Article ID: 939161.

[13] Adriano, D.C. (1986) Trace Element in the Terrestrial Environment. Springer-Verlag, New York. http://dx.doi.org/10.1007/978-1-4757-1907-9

[14] Dhar, R.K., Biswash, B.K., Samanta, G., Mandal, B.K., Chakraborti, D., Roy, S., Jafar, A., Islam, A., Ara, G.M. and Kabir, S. (1997) Ground Water Arsenic Calamity in Bangladesh. Current Science, 73, 48-59.

[15] Dhankher, O.P., Rosen, B.P., McKinney, E.C. and Meagher, R.B. (2006) Hyperaccumulation of Arsenic in the Shoot of Arabidopsis silenced for Arsenate Reductage. Proceedings of the National Academy of Sciences of the United States of America, 103, 5413-5418. http://dx.doi.org/10.1073/pnas.0509770102

[16] Eugenio, F.B. (2008) Are More Restrictive Food Cadmium Standards Justifiable Health Safety Measures or Opportunistic Barriers to Trade? An Answer from Economics and Public Health. Science of the Total Environment, 389, 1-9. http://dx.doi.org/10.1016/j.scitotenv.2007.08.015

[17] Smith, E., Juhasz, A.L. and Weber, J. (2009) Arsenic Uptake and Speciation in Vegetable Grown under Greenhouse Conditions. Environment and Geochemical Health, 31, 125-132. http://dx.doi.org/10.1007/s10653-008-9242-1

[18] Naidu, R., Smith, E., Owens, G., Bhattacharya, P. and Nadebaum, P. (2006) Managing Arsenic in the Environment: From Soil to in the Environment: From Soil to Human Health. CSIRO publishing, Melbourne, 565 p.

[19] Bhattacharya, P., Mukherjee, A.B., Bundschuh, J., Zevenhoben, R. and Loeppert, R.H. (2007) As in Soil and Ground Water Environment: Biogeochemical Interactions, Health Effects and Remediation. Trace Metals and Other Contaminants in the Environment, Book 9, 645.

[20] Nwaichi, E.O. and Dhankher, O.P. (2016) Heavy Metals Contaminated Environments and the Road Map with Phytoremediation. Journal of Environmental Protection, 7, 41-51. http://dx.doi.org/10.4236/jep.2016.71004

[21] Genc-Furham, H., Tjell, J.C. and McConchie, D. (2004) Increasing the Arsenate Adsorption Capacity of Neutralised Red Mud. Journal of Colloid Interface Science, 271, 313-320. http://dx.doi.org/10.1016/j.jcis.2003.10.011

[22] Genc-Furham, H., McConchie, D. and Schuiling, O. (2005) Comparing the Arsenic Sorption Capacity of Bauxsol and Its Derivatives with Other Sorbent. In: Bhattacharya, P., Bundschuh, J. and Chandrasekharam, D., Eds., Natural Arsenic in Ground Water: Occurrence Remediation and Management, Balkema, London, 223-235.

[23] Salt, D.E., Smith, R.D. and Raskin, I. (1998) Phytoremediation. Annual Review of Plant Physiology and Plant Molecular Biology, 49, 643-668. http://dx.doi.org/10.1146/annurev.arplant.49.1.643

[24] Pilon-Smits, E. (2005) Phytoremediation. Annual Review of Plant Biology, 56, 15-39.

http://dx.doi.org/10.1146/annurev.arplant.56.032604.144214

[25] Kabata-Pendias, A. (2011) Trace Elements in Soils and Plants. CRC Press, Boca Raton.

[26] Chaney, R.L. (1983) Plant Uptake of Inorganic Waste Constituents. In: Parr, J.F., Marsh, P.D. and Kla, J.M., Eds., Land Treatment of Hazardous Wastes, Noys Data, Park Ridge, 50-76.

[27] Salt, D.E., Blaylock, M., Kumar, P.B.A.N, Dushenkov, V., Ensley, B.D., Chet, L. and Raskin, L. (1995) Phytoremediation: A Novel Strategy for the Removal of Toxic Metals from the Environment Using Plants. Biotechnology, 13, 468-474. http://dx.doi.org/10.1038/nbt0595-468

[28] Islam, M.S., Wahid-Uz-Zaman, M. and Rahman, M.M. (2013) Phytoaccumulation of Arsenic from Arsenic Contaminated Soils by Eichhornia crassipes L., Echinochloa crusgalli L. and Monochoria hastata L. in Bangladesh. International Journal of Environmental Protection, 3, 17-27.

[29] Macnair, M.R. (2003) The Hyperaccumulation of Metals by Plants. Advances in Botanical Research, 40, 64-106. http://dx.doi.org/10.1016/s0065-2296(05)40002-6

[30] Rahman, M., Haq, N. and Williams, I.D. (2012) Genetic Effect on Phytoaccumulation of Arsenic in Brassica juncea L. Euphytica, 186, 409-417. http://dx.doi.org/10.1007/s10681-012-0632-1

[31] Chaturvedi, I. (2006) Effect of Arsenic Concentrations and Forms on Growth and Arsenic Uptake and Accumulation by Indian Mustard (Brassica juncea). Journal of Central European Agriculture, 7, 31-40.

[32] Prasad, M.N.V. and Freitas H.M.D.O. (2003) Metal hyperaccumulation in Plants-Biodiversity Prospecting for Phytoremediation Technology. Molecular Biology and Genetics, 6, 25-42.

[33] Gomez, K.A. and Gomez, A.A. (1983) Statistical Procedures for Agricultural Research. John Wiley, Hoboken.

[34] Hoagland, D.R. and Arnon, D.I. (1950) The Water-Culture Method of Growing Plants without Soil. Californian Agricultural Experimental Station. Circular, 347, 1-32. 
[35] Baldwin, P.R. and Bucher, D.J. (2007) Phytoremediation of Arsenic by Two Hyperaccumulators in a Hydroponics Environment. Microchemical Journal, 85, 297-300. http://dx.doi.org/10.1016/j.microc.2006.07.005

[36] Brown, S.L., Chaney, R., Angle, J.S. and Baker, A.J.M. (1995) Zinc and Cadmium Uptake by Hyperaccumulator Thlaspi caerulescence Grown in Nutrient Solution. Soil Science Society American Journal, 59, 125-133. http://dx.doi.org/10.2136/sssaj1995.03615995005900010020x

[37] Pollard, A.J. and Baker, A.J.M. (1996) The Quantitative Genetics of Zinc Hyperaccumulation in Thalspi caerulescense. New Phytology, 132, 113-118. http://dx.doi.org/10.1111/j.1469-8137.1996.tb04515.x

[38] Lasat, M.M. (2002) Phytoextraction of Toxic Metals: A Review of Biological Mechanisms. Journal of Environmental Quality, 31, 109-120. http://dx.doi.org/10.2134/jeq2002.0109

[39] Kumar, P.B.A.N., Dushenkov, V., Motto, H. and Raskin, L. (1995) Phytoextraction: The Use of Plants to Remove Heavy Metals from Soils. Environmental Science and Technology, 29, 1232-1238. http://dx.doi.org/10.1021/es00005a014

[40] Cox, M.S., Bell, P.F. and Kovar, J.L (1996) Differential Tolerance of Canola to Arsenic When Grown Hydroponically or Soil. Journal of Plant Nutrition, 19, 1599-1610. http://dx.doi.org/10.1080/01904169609365224

[41] Steel, R.G.D. and Torrie, J.H. (1984) Principles and Procedures of Statistics: A Biometrical Approach. McGraw Hill Book Co., New York.

[42] Cohen, C.K., Fox, T.C., Garvin, D.F. and Kochian, L.V. (1998) The Role of Iron-Deficiency Stress Responses in Stimulating Heavy Metal Transport in Plants. Plant Physiology, 116, 1063-1072. http://dx.doi.org/10.1104/pp.116.3.1063

[43] Brown, J.C. (1978) Mechanism of Iron Uptake by Plants. Plant, Cell and Environment, 1, 249-257. http://dx.doi.org/10.1111/j.1365-3040.1978.tb02037.x

[44] Bao, T. and Sun, L.N. (2008) Evaluation of Iron on Cadmium Uptake by Lycopersicon esculentum Mill. in Hydroponic Culture. The 2nd International Conference on Bioinformatics Biomedical Engineering, Shanghai, 16-18 May 2008, 4108-4112.

[45] Tu, C. and Ma, L.Q. (2002) Effect of Arsenic Concentration and Forms on Arsenic Uptake by the Hyperaccumulator Ladder Brake. Journal of Environmental Quality, 31, 641-647. http://dx.doi.org/10.2134/jeq2002.0641

[46] Gupta, M., Sharma, P., Sarin, N.B. and Sinha, N.K. (2009) Differential Responses of Arsenic Stress in Two Varieties of B. juncia L. Chemosphere, 74, 1201-1208. http://dx.doi.org/10.1016/j.chemosphere.2008.11.023

[47] Yadav, S.K. (2010) Heavy Metals Toxicity in Plants: An Overview on the Role of Glutathione and Phytochelatins in Heavy Metal Stress Tolerance of Plants. South African Journal of Botany, 76, 167-179. http://dx.doi.org/10.1016/j.sajb.2009.10.007

[48] Grill, E., Winnaker, E.L. and Zenk, M.H. (1985) Phytochelatine: The Principle Heavy Metal Complexing Peptides of Higher Plants. Science, 230, 674-676. http://dx.doi.org/10.1126/science.230.4726.674

[49] Schmoger, M.E.V., Oven, M. and Grill, E. (2000) Detoxification of Arsenic by Phytochelatins in Plants. Plant Physiology, 122, 793-801. http://dx.doi.org/10.1104/pp.122.3.793

[50] Pickering, I.J., Prince, R.C., George, M.J., Smith, R.D., George, G.N. and Salt, D.E. (2000) Reduction and Coordination of Arsenic in Indian Mustard. Plant Physiology, 122, 1171-1177. http://dx.doi.org/10.1104/pp.122.4.1171

[51] Jocelyn, P.C. (1972) Biochemistry of the SH Group: The Occurrence, Chemical Properties, Metabolism and Biological Function of Thiols and Disulphides. Academic Press, London.

[52] Ullrich-Eberius, C.I., Sanz, A. and Novacky, J. (1989) Evaluation of Arsenate- and Vanadate-Associated Changes of Electrical Membrane Potential and Phosphate Transport in Lemna gibba G1. Journal of Experimental Botany, 40, 119-128. http://dx.doi.org/10.1093/jxb/40.1.119

[53] Falconer, D.S. and Mackay, T.F.C. (1996) Introduction to Quantitative Genetics. 4th Edition, Pearson Education Ltd, Essex.

[54] Salt, D.E., Prince, R.C., Pickering, I.J. and Raskin, I. (1995) Mechanism of Cadmium Mobility and Accumulation in Indian Mustard. Plant Physiology, 109, 1427-1433.

[55] Fujimura, T., Wang, L. and Higashi, T. (2004) Uptake of Cadmium and Inorganic Nutrients by Brassica Plant under Water Culture Condition. Japanese Journal of Soil Science and Plant Nutrition, 75, 329-337.

[56] Vatehova, Z., Kollarova, K., Zelko, I., Richterova-Kucerova, D., Bujdos, M. and Liskova, D. (2012) Interaction of Silicon and Cadmium in Brassica juncea and Brassica napus. Biologia, 67, 498-504. http://dx.doi.org/10.2478/s11756-012-0034-9

[57] Wue, F., Dong, J., Chen, F. and Zhang, G. (2005) Response of Cadmium Uptake in Different Barley Genotypes to Cadmium Level. Journal of Plant Nutrition, 28, 2201-2209. http://dx.doi.org/10.1080/01904160500324741 
[58] Verma, S. and Dubey, R.S. (2003) Lead Toxicity Induces Lipid Peroxidation and Alters the Activities of Antioxidant Enzymes in Growing Rice Plants. Plant Science, 164, 645-655. http://dx.doi.org/10.1016/S0168-9452(03)00022-0

[59] Liu, D., Jiang, W., Liu, C. and Hou, C. (2000) Uptake and Accumulation of Lead by Root Hypocotyls and Shoots of Indian Mustard (Brassica juncea L.). Bioresource Technology, 71, 273-277. http://dx.doi.org/10.1016/S0960-8524(99)00082-6

[60] Meyers, D.E.R., Auchterlonie, G.J., Webb, R.I. and Wood, B. (2008) Uptake and Localisation of Lead in the Root System of Brassica juncea. Environmental Pollution, 153, 323-332. http://dx.doi.org/10.1016/j.envpol.2007.08.029

[61] Jones, L.H.P., Clement, C.R. and Hopper, M.J. (1973) Lead Uptake from Solution by Perennial Ryegrass and Its Transportation from Roots to Shoots. Plant Physiology, 38, 403-414.

[62] Lane, S.D. and Martin, E.S. (1980) Further Observations on the Distribution of Lead in Juvenile Roots of Raphanus sativus. Journal of Plant Physiology, 97, 145-152. http://dx.doi.org/10.1016/s0044-328x(80)80028-6

[63] Clarke, T. (2003) Delta Blues. Nature, 422, 254-256. http://dx.doi.org/10.1038/422254a

[64] Prakash, S. (1980) Cruciferous Oilseeds in India. In: Tsunoda, S., Hinata, K. and GomezCampo, C., Eds., Brassica Crops and Wild Allies, Biology and Breeding, Japan Scientific Societies Press, Tokyo, 151-166.

[65] Kimber, D.S. and McGregor, D.I. (1995) The Species and Their Origin, Cultivation and World Production. In: Kimber, D. and McGregor, D.I., Eds., Brassica Oilseeds, Production and Utilization, CAB International, Wallingford, 1-7. 